Environmental Biology of Fishes

February 2016, Volume 99 Issue 2 Pages 171-178

http://dx.doi.org/10.1007/s10641-015-0464-7

http://archimer.ifremer.fr/doc/00299/40993/

(c) Springer Science+Business Media Dordrecht 2015

\title{
Identification of skipjack tuna juveniles based on DNA control region sequences and potential spawning area around reunion island
}

Nikolic Natacha ${ }^{1,{ }^{*}}$, Jérôme Marc ${ }^{2}$, Fonteneau Alain ${ }^{3}$, Evano Hugues ${ }^{1}$, Verrez-Bagnis Veronique ${ }^{2}$

${ }^{1}$ IFREMER, Institut Français de Recherche pour l'Exploitation de la Mer, Délégation de La Réunion, Rue Jean Bertho, BP 60, 97822 Le Port Cedex, La Réunion, France

${ }^{2}$ IFREMER, rue de l'lle d'Yeu, BP 21105, F-44311 Nantes 03, France

${ }^{3}$ IRD, UMR EME 212, avenue Jean Monnet CS30171, 34203 Sète Cedex, France

*Corresponding author : Natacha Nikolic, email address : natachanikolic@hotmail.com

\begin{abstract}
:
In this study, we confirmed that DNA control region can be used to identify potential spawning area from pelagic juveniles species. We used the mitochondrial DNA control region to identify tuna juveniles predated by common dolphinfish and sampled in surface waters around Reunion Island. These were skipjack juveniles at an early stage (small length and young age). The biological results confirmed the species identification based on DNA analysis. Catch data by longline reveal a higher number of skipjack from October to December around Reunion Island corresponding to the period of our skipjack juvenile sampling
\end{abstract}

Keywords : Skipjack tuna, Reunion island, DNA, Age, Juvenile 


\section{Introduction}

The skipjack tuna, Katsuwonus pelamis (Linnaeus 1758) (Osteichthyes: Scombridae), is a pelagic and migratory fish widely distributed from tropical to subtropical waters (Collette and Nauen, 1983). It is generally considered to inhabit surface waters (100-200 m) (Kenneth 1963), and is heavily exploited by surface fisheries. In the Indian Ocean, skipjack tuna represents almost half of the total catch of tropical tuna (Dueri and Maury, 2013), and the fishery is one of the largest tuna fisheries in the world with total catches of 400-600 000 t over the last decade (IOTC 2014). The 2014 stock status determination is that the stock is not overfished and not subject to overfishing (IOTC 2014). Since the 1980s, catches of skipjack tuna have considerably increased, peaking in 2006 due to the development of industrial purse seining and the concurrent rise of gillnet catches and bait boats (IOTC 2014). Since 2007, this species seems to have declined in the Indian Ocean as evidence in a decrease in surface fishery catches (IOTC 2014; Fonteneau 2014).

AQ1

AQ2

In the Atlantic and the Pacific Oceans, several authors have studied the reproduction of this species (e.g. Schaefer and Orange 1956; Batts 1972, Matsumoto et al. 1984; Cayre and Farrugio 1986; Batalyants 1989; Schaefer 2001 ; Ashida et al. 2010). In the Indian Ocean, the majority of studies are from the Western part (e.g. Raju 1964; Stéquert 1976; Stéquert and Ramcharrun 1995, 1996; Stéquert et al. 2001; Grande et al. 2012). This species does not follow clear spawning or feeding migration patterns (Stéquert and Ramcharrun 1996) but rather exhibits home range movements within habitat preferences (Dueri and Maury, 2013). Skipjack tuna are believed to spawn multiple times in areas where the sea surface temperature is higher than $24{ }^{\circ} \mathrm{C}$ (Matsumoto et al. 1984; Buñag 1956). In the Western Indian Ocean, the first maturity for females and males is around $40 \mathrm{~cm}$, with two apparent, main spawning periods (November-March; June-August) (Stéquert and 
Ramcharrun 1996). Small skipjack are recruited by the Indian Ocean fisheries at sizes between 35 and $40 \mathrm{~cm}$, meaning that juvenile skipjack are seldom fished. Sampling of early juvenile skipjack tuna is very difficult and no datasets exist. In order to increase reproductive information and to open the debate on potential spawning areas, we report here a study on early juveniles of skipjack collected around Reunion Island.

AQ3

In this paper, we present the usefulness of molecular tool for the identification of potential spawning areas of Skipjack tuna in Indian Ocean. Skipjack tuna are defined as juvenile until they have acquired the coloration and body form of adults (length of about 20-25 cm) (Kenneth 1963). The method of species identification used in this study is based on a Bartlett and Davidson study (1992) that developed a direct sequence analysis (the Forensically Informative Nucleotide Sequencing method or "FINS") to identify the Thunnus tuna species and on a Viñas and Tudela (2009) study that tested the FINS method on tuna species using the sequence variability of the hypervariable genetic marker mitochondrial DNA control region (mtDNA CR). Genetic samples are easier to preserve particularly on a boat, than a frozen whole individuals. Owing to the high variability of the mtDNA control region and the missing species in the international sequences database, we completed molecular taxonomy approach by traditional (morphological) taxonomy approach in order to confirm our results.

\section{Materials and methods}

\section{Samples}

All of the fish were sampled from a French vessel at sea in the authorized marine waters. The field studies did not involve endangered or protected species. The collected and sampled fish are considered commercial species (mainly tuna, skipjack, common dolphinfish, and billfishes) all over the world and do not fall under any official, ethical rules (UICN, RED list). No specific permissions were required for the sampling locations (Fig. 1).

\section{Fig. 1}

Geographic location of fishery sets from the project GERMON ( ${ }^{\circ} 759 /$ DMSOI /2013) 


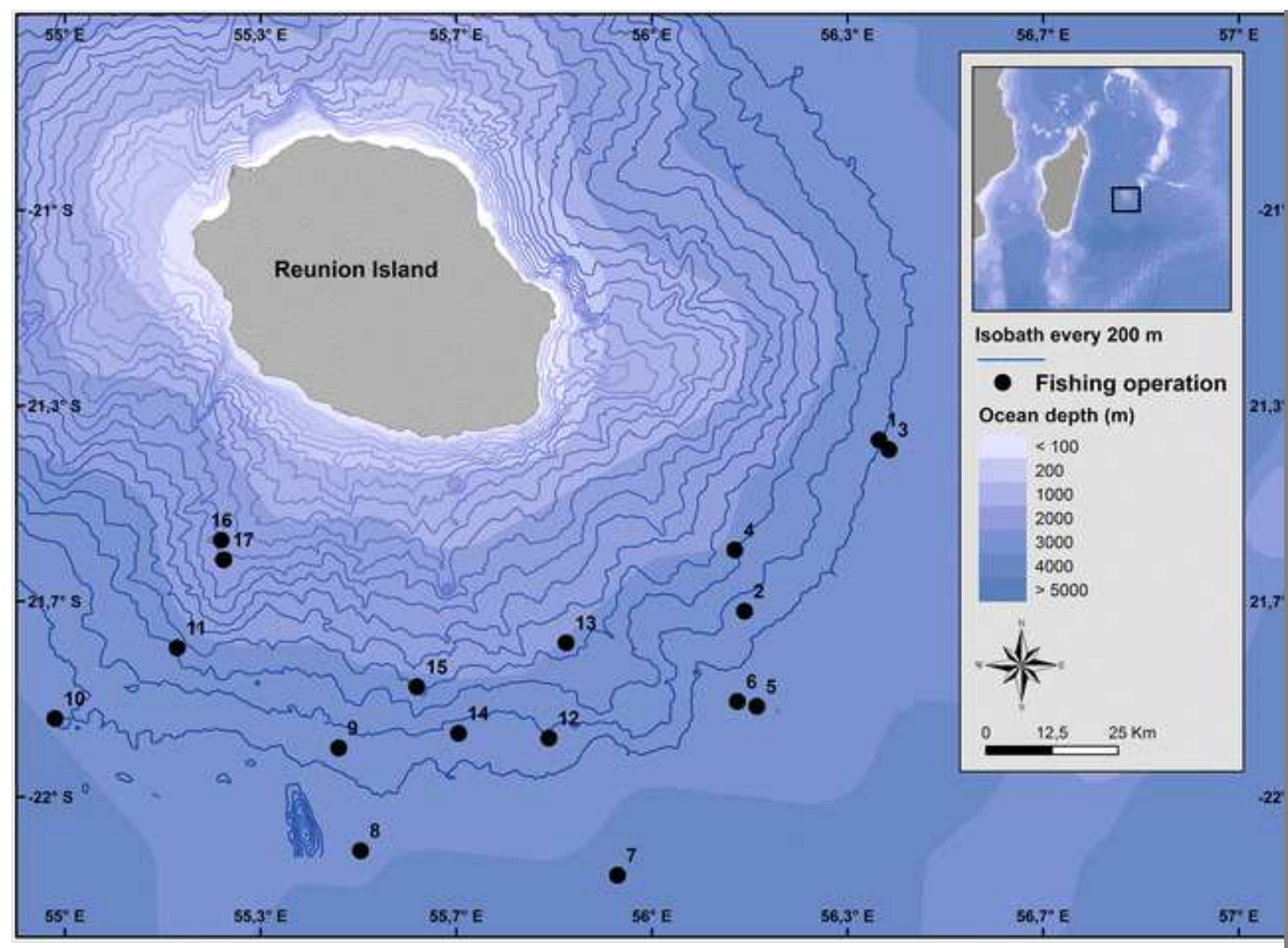

We observed predated, unknown, early juveniles during the 17 sets (from 15 November 2015 to 01 December 2015, one set by day) and during sunset following bait fishing ( $150 \mathrm{~g}$ of squid (Illexargentinus)) at the surface of one hundred individuals. During the 17 days, the minimum average temperature was $26.9{ }^{\circ} \mathrm{C}$ and the maximum average was $27.3^{\circ} \mathrm{C}$. The average depth of fishing operations was $50 \mathrm{~m}$ with a maximum of $131 \mathrm{~m}$. Early juveniles of unknown species were collected from the mouths of common dolphinfish, Coryphaena hippurus, during this scientific expedition around Reunion Island (project GERMON). Two individuals (XB103 and XB105) predated by common dolphinfish were collected on 29 November $2015\left(21^{\circ} 47 \mathrm{~S}\right.$ and $55^{\circ} 27 \mathrm{E}$; surface temperature $27.1-27.7^{\circ} \mathrm{C}$; depth of the fishing line $21-62 \mathrm{~m}$ ) and sequenced. Their biological characteristics were also collected and opercular bones were removed.

\section{Genetic analysis}

\section{DNA extraction}

The method for DNA extraction followed the standard protocol for Charge Switch Forensic DNA Purification Kit (Invitrogen) described in Lelièvre et al. 
(2010) with slight modifications. Total genomic DNA was isolated from a small piece of individual tissue (approximately $100 \mathrm{mg}$ ), one of the early juveniles sampled. The tissue was processed for $1 \mathrm{~h}$ at $55^{\circ} \mathrm{C}$ in a $1.5 \mathrm{~mL}$ microcentrifuge tube containing $1 \mathrm{~mL}$ of lysis buffer and $10 \mu \mathrm{L}$ of proteinase $\mathrm{K}(20 \mathrm{mg} / \mathrm{mL})$. Then, $200 \mu \mathrm{L}$ of purification buffer and $20 \mu \mathrm{L}$ of magnetic beads were added to the microcentifuge tube and the mixture was left at room temperature for $1 \mathrm{~min}$. The tube was then placed on a magnetic rack and, after immobilization of beads, the supernatant was removed and discarded. Beads were washed two times using $500 \mu \mathrm{L}$ of washing buffer each time. The DNA was eluted by adding $150 \mu \mathrm{L}$ of elution buffer and, after 1 min of incubation at $55{ }^{\circ} \mathrm{C}$, recovered and stored at $4{ }^{\circ} \mathrm{C}$ for subsequent tasks.

\section{PCR and sequencing of the mitochondrial control region}

A Polymerase Chain Reaction (PCR) was used to amplify an approximately $450 \mathrm{bp}$ segment of the mitochondrial control region (CR) using the primer pair L15998 and CSBDH, (Alvarado Bremer 1994). The amplification was carried out in accordance with the findings of Viñas and Tudela (2009) with slight modifications. In all cases, the PCR reactions were carried out in a total volume of $50 \mu \mathrm{L}$ with the following composition: 0.5 to $2.5 \mu \mathrm{L}$ DNA template were added to a PCR mix consisting of $0.2 \mathrm{mM}$ dNTP each (Interchim), $2 \mathrm{mM}$ $\mathrm{MgCl}_{2}, 10 \mu \mathrm{L} 5 \mathrm{X}$ buffer, 1.25 units of GoTaq polymerase (Promega), $0.2 \mu \mathrm{M}$ of each primer and molecular biology grade water (Interchim) to comprise the final volume. PCRs were carried out in a MyCycler ${ }^{\mathrm{TM}}$ thermocycler (BioRad). Conditions of cycling were as follows: an initial denaturing step at $94{ }^{\circ} \mathrm{C}$ for 5 min, followed by 35 cycles of denaturing at $94{ }^{\circ} \mathrm{C}$ for $45 \mathrm{~s}$, annealing at $50{ }^{\circ} \mathrm{C}$ for $45 \mathrm{~s}$, extension at $72{ }^{\circ} \mathrm{C}$ for $1 \mathrm{~min}$, and a final extension step at $72{ }^{\circ} \mathrm{C}$ for $7 \mathrm{~min}$. The DNA amplification was controlled on $1.5 \%$ agarose gels (Interchim), using TAE buffer (2 mM EDTA, 40 mMTris acetate, pH 8.5), and amplicons were quantified using a low range MassRuler ${ }^{\mathrm{TM}}$ DNA ladder mix (MBI Fermentas). GelRed ${ }^{\mathrm{TM}}$ (Interchim) was used for visualization of doublestranded products through ultraviolet transillumination (Gel Doc ${ }^{\mathrm{TM}} \mathrm{XR}$, BioRad). Finally, PCR fragments were used for direct cycle sequencing, and sequences were performed in both directions with the primers used for PCR amplification using DNA sequencing services (Genoscreen facilities, Lille, France).

\section{Genetic taxonomy}

The FINS technique described by Bartlett and Davidson (1992) has been used to identify the "unknown early juvenile fish" (XB103 and XB105). The basis 
of this technique is the comparison of sequences of unknown samples with sequences belonging to pattern specimens.

All alignments of sequences were performed on BioEdit software (Hall 1999 ). Sequences were compared with nucleotide sequences from GenBank (National Center for Biotechnology Information, NCBI) with the program BLAST (Basic Local Alignment Search Tool).

A phenogram was constructed to confirm the BLAST results using the Neighbor joining method (Saitou and Nei 1987) with MEGA6 (Tamura et al. 2013 ). The analysis involved 11 nucleotide sequences from GenBank database, including the consensus sequences of the two early juveniles and tuna sequences.

\section{Morphological taxonomy}

The manual of Smith and Heemstra (1986) was used to determinate the species of samples collected. This manual presents diagnostic features of representative species for each family. To identify a perciform fish, the fin formula keys to bony fishes construed by J.L.B. Smith has been used. The form of body (elongated and fusiform) and others biological features (snout pointed; premaxillae beak-like; free from nasal bones which are separated by ethmoid bone; finlets present behind dorsal and anal fins) corresponded to the scombridae family. To determinate the species from the corresponding family, the number of fins and finlets was counted.

\section{Nominal catch}

Total nominal catches of skipjack tuna from the Indian Ocean Tuna

Commission (IOTC) ( http://www.iotc.org/English/data/databases.php ) were used to determinate the period of adult presence in surface around Reunion Island.

\section{Determination of age}

Images of the opercular bone were obtained with the microscopes LEICA and ZEISS under reflected light and stored with high resolution (3200 dpi). Image processing was performed using the image analysis system TNPC (Digital processing for calcified structures, version 7, www.tnpc.fr ).

\section{Results}


According to the DNA sequences, the juveniles were identified as Katsuwonus pelamis by sequence comparison using BLAST in GenBank database. Based on 449 DNA base pairs, the query sequence was $100 \%$ covered and had respectively $99 \%$ for XB103 juvenile and $98 \%$ for XB105 juvenile of identify with Katsuwonus pelamis sequences present in the GenBank nucleotide database.

The phylogeny analysis, from the mitochondrial DNA control region, has been carried out allowing also the identification of the two "unknown early juvenile fish" as Katsuwonus pelamis (Fig. 2). This confirms the result obtained by the BLAST results.

Fig. 2

AQ4

Phenogram from the mitochondrial DNA control region based on genetic distance using Neighbor joining method (Saitou and Nei 1987) with the unknown early juvenile samples ("unknown species") and the multiple alignment of tuna and bonito species. The GenBank accession number for each sequence is given adjacent to the corresponding species. The robustness of topology nodes was tested by the bootstrap method with 1000 iterations. The percentage of replicate trees in which the associated taxa clustered together in the bootstrap test is shown next to the branches (Felsenstein 1985). The distances were computed using the number of difference method (Nei and Kumar 2000) and are in the units of the number of base difference per sequence. All positions containing gaps and missing data were eliminated
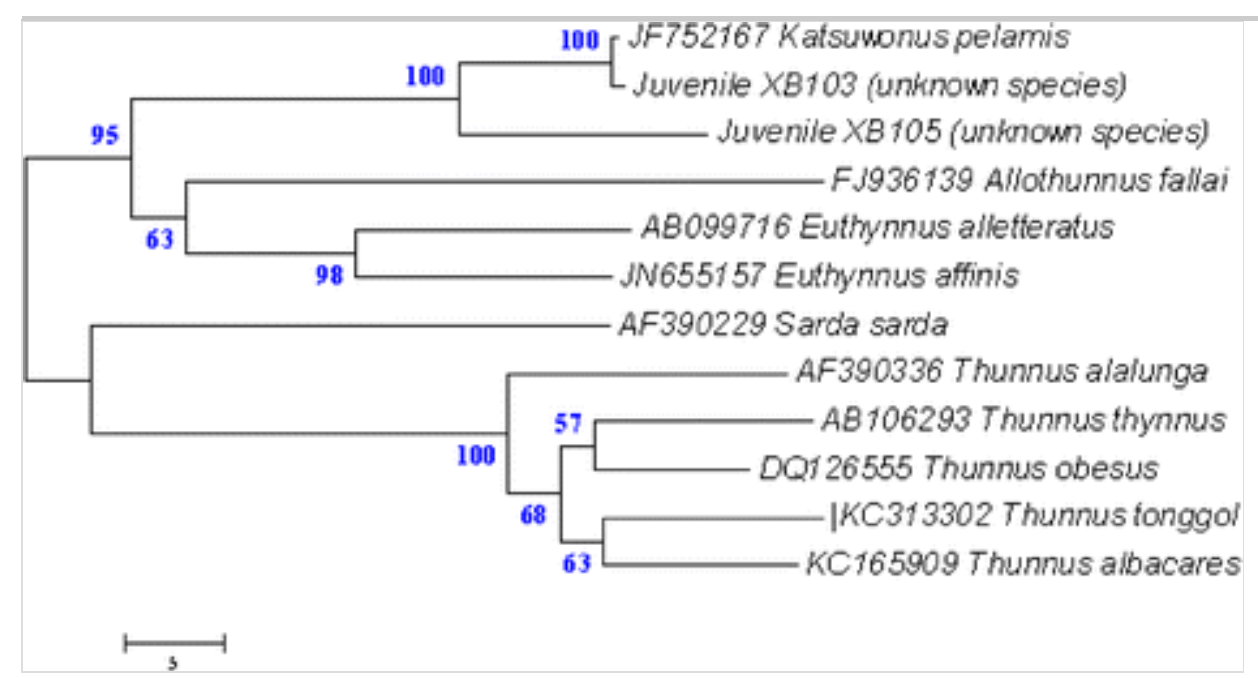

\section{Morphological taxonomy and biological characteristics}

The fork length and biological characteristics (Fig. 3 ) of the two sampled 
juveniles were analyzed. The fork length range was $10.2 \mathrm{~cm}$ and total length $10.9 \mathrm{~cm}( \pm 0.1)$ (Fig. 3), which was around the same for the other early juvenile. The number of hard dorsal fins was 15 and smooth dorsal was 14 (Fig. 4). The number of finlets was equal to 8 . These biological characteristics correspond to Katsuwonus pelamis (Smith and Heemstra 1986 ). This confirms the result obtained by the genetic analysis determination.

\section{Fig. 3}

Body length $(\mathrm{cm})$ and fin localization of early juvenile skipjack tuna

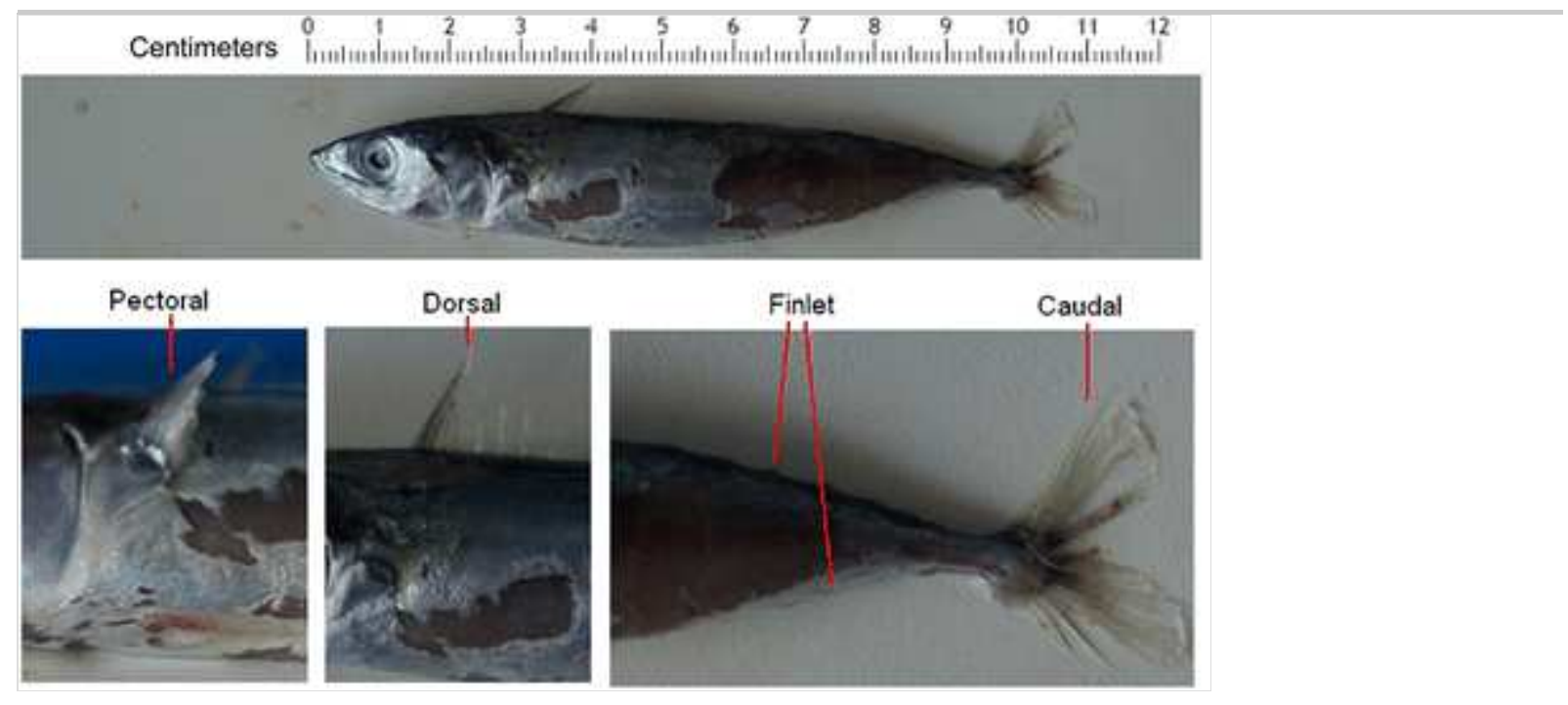

Fig. 4

Number of dorsal fins of early juvenile skipjack tuna

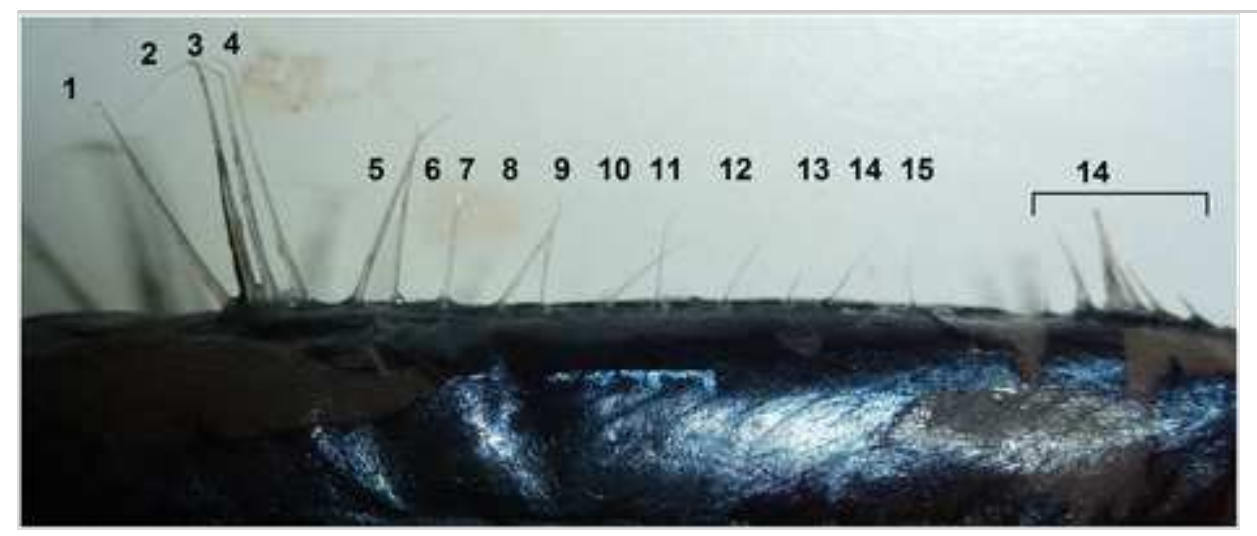

Age, in number of days, was estimated from the opercular bone (Fig. 5). Based on the counting of growth rings assumed to be deposited each day, the aging of 16-20 days was estimated for each individual with uncertainty as to 4 possible growth rings (Fig. 5).

Fig. 5 
Opercular bone of skipjack tuna with black points (left side) representing estimated daily rings and red points corresponding to uncertain daily rings

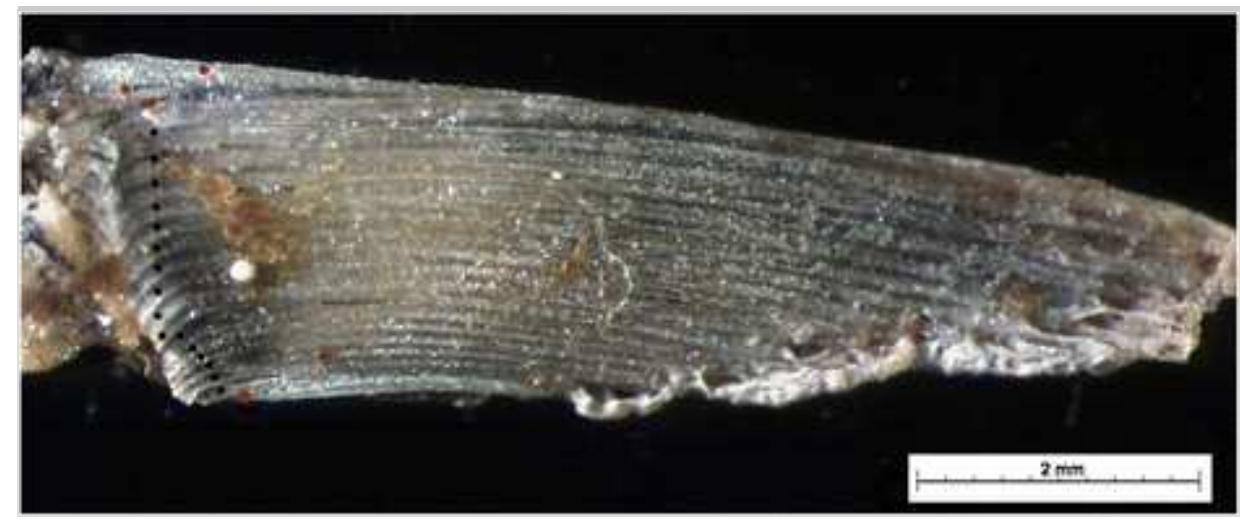

\section{Adult skipjack geographic and temporal distribution}

Adult skipjack tuna are caught by longliners in a wide habitat in the Indian Ocean. They are predominantly caught in warm surface waters $\left(10^{\circ} \mathrm{N}-10^{\circ} \mathrm{S}\right)$ but also at southern latitudes $\left(10^{\circ} \mathrm{S}-40^{\circ} \mathrm{S}\right)$. The seine fishing is very important in the Indian Ocean but not present around the Reunion Island, this explains the longliners mapping. The total catches per month of skipjack tuna by longliners in the southwest of the Indian Ocean closed to study localization $\left(10-30^{\circ} \mathrm{S}\right.$ and $\left.45-70^{\circ} \mathrm{E}\right)$ show an increase from October to December. The skipjack tuna is present around Reunion Island during the fourth quarter (Fig. 6 ). Seasonal skipjack tuna fished by Japanese longlines in the southwest of the Indian Ocean and in warm sea surface waters (superior to $25^{\circ} \mathrm{C}$ ) are favorable for spawning (Fig. 7). Hence, around Reunion Island, the spawning period seems to be in the fourth quarter (Figs. 6 and $7-$ blue color) corresponding to the same sampling quarter of our study.

\section{Fig. 6}

Total monthly catches of skipjack tuna declared by longliners, in number of individuals, per month in the southwest Indian Ocean $\left(10-30^{\circ} \mathrm{S}\right.$ and $\left.45-70^{\circ} \mathrm{E}\right)$ 


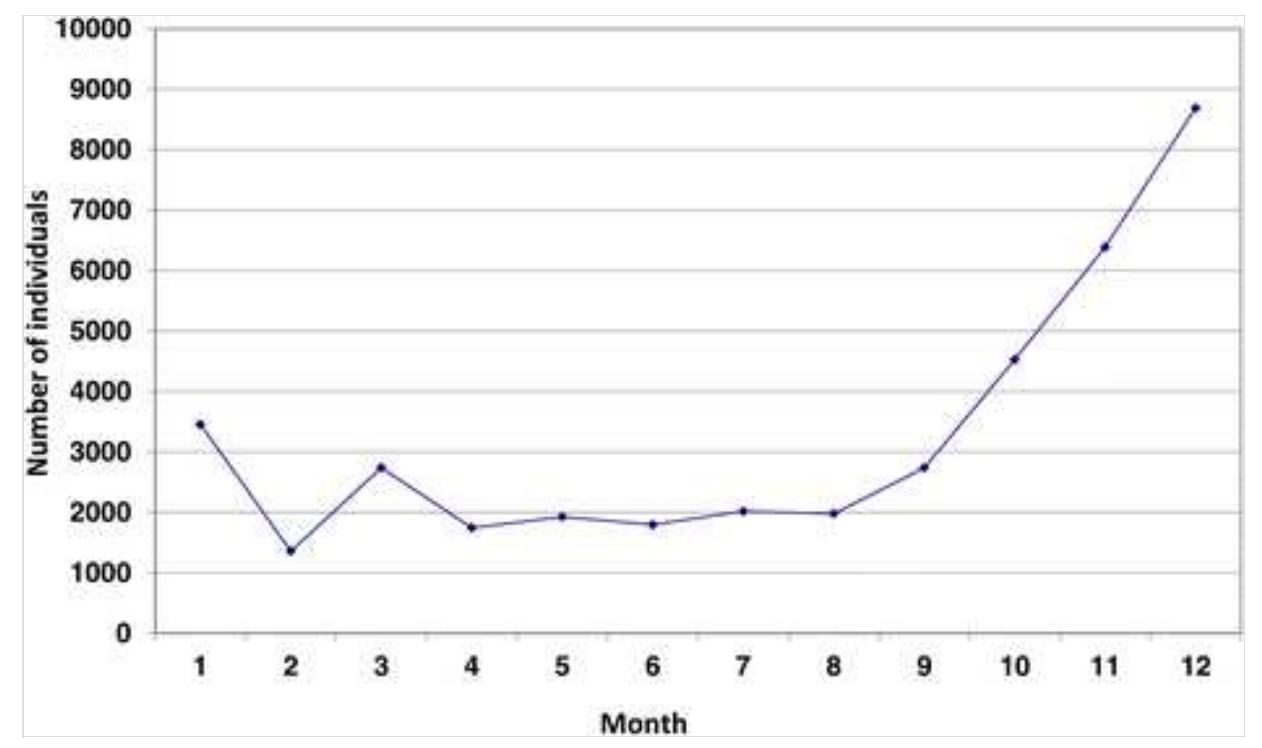

\section{Fig. 7}

Average catch of skipjack tuna from 1955 to 2013 in warm waters (superior $25^{\circ} \mathrm{C}$ ) by statistical square $\left(5^{\circ}\right)$ and quarter (1 (black), 2 (turquoise), 3 (red) and 4 (blue)) by Japanese longliners. Each circle shows a surface proportional to the catch and positioned in the $5^{\circ}$ square of the reported catch

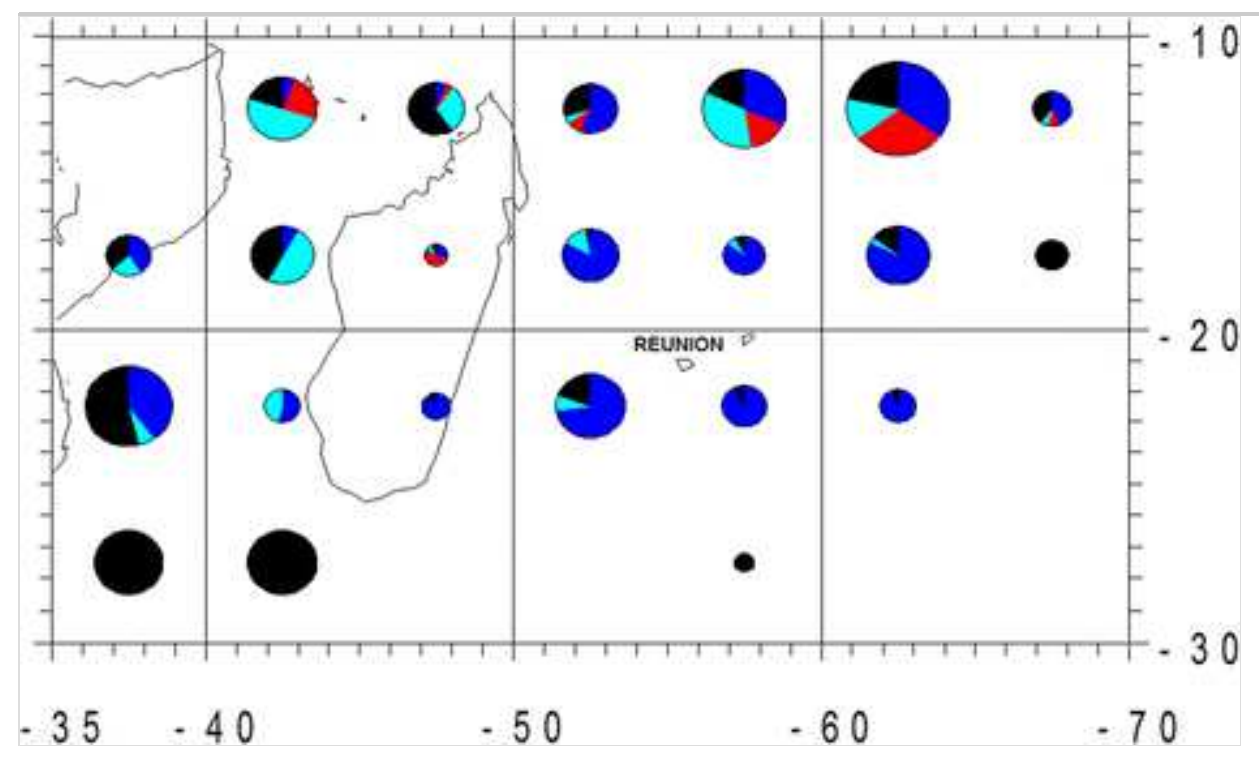

\section{Discussion}

The early juveniles predated by common dolphinfish and collected around Reunion Island have been identified by the genetic and biological characteristics as being skipjack tuna (Katsuwonus pelamis).

The mitochondrial DNA control region (mtDNA CR) marker was chosen based on the Viñas and Tudela (2009) study because they found that mtDNA CR based tree allowed a full discrimination of all Thunnus species, probably 
as a consequence of its greater genetic variability. In our study, the identification using BLAST was confirmed by the FINS approach. The genetic relationship, based on the mtDNA CR tree shows a clear separation between tuna and bonito, and especially between Katsuwonus genus and the Thunnus genus (Michelini et al. 2007; Kumar et al. 2014) and supported the monophyletic origin of Thunnus species (Kumar et al. 2014).

In the literature, the smaller early juvenile in the Indian Ocean was described as $27 \mathrm{~mm}$ total length and the larger (older larvae) was $7.08 \mathrm{~mm}$ (Jones 1959 ); and there were no samples reported by scientists in this size range. To our knowledge, it is the first time that an early juvenile of skipjack in the Indian Ocean has been described at $10.9 \mathrm{~cm}$ total length and with an estimated age.

In the past, skipjack larvae have been observed around Reunion Island (Nishikawa et al. 1985). The catches of skipjack tuna by longline in potential spawning water (individuals larger than $40 \mathrm{~cm}$ and in warm water with temperatures superior to $24-25^{\circ} \mathrm{C}$ ) in the southwest of the Indian Ocean reveal a potential spawning area around Reunion Island during the fourth quarter. The aging of 16-20 days, estimated here on the basis of the opercular bone, would indicate that these two skipjack juveniles were born at the beginning of November 2015. This result is consistent with longline catches showing a potential spawning period from October to January in the southwest Indian Ocean.

Large-scale movements of skipjack tuna have been observed in the Indian Ocean, probably more than in some other oceans, with fish observed distances from a mark-recapture program achieving average distances of 600 miles in less than 3 months and average total distances over 1000 miles (Fonteneau and Hallier 2015). The major seasonal and inter-annual variability of the Indian oceanographic conditions (Marsac and Le Blanc 19998; Ménard et al. 2007) may explain these active movements. Higher nominal catches of skipjack tuna are from the equatorial band of the Western Indian Ocean, but average analysis from a long series of data reveal a small but consistent peak of skipjack catches during the fourth quarter around Reunion Island. This presence of skipjack around Reunion Island mainly between November and January may be a consequence of environmental conditions such as temperature, dissolved oxygen concentration, and prey availability. These parameters play a role in the spatial distribution, movement, and catchability of skipjack tuna (Barkley et al. 1978; Brill 1994; Brill and Lutcavage 2001). 
We can assume the existence of a specific seasonal spawning area, which explains the specific period of early juveniles collected around Reunion Island.

AQ5

\section{Acknowledgments}

This research was supported by European Fisheries Funds EU FEP (GERMON project - http://wwz.ifremer.fr/lareunion/Les-projets/GERMONen-cours ). We acknowledge all the MANOHAL team (Stéphan, Pascal, Olivier, Fata and Joachin) and particularly Jean-Marc Tatibouët and Jean Hugues Lamy. We acknowledge Michel Potier (IRD) for his help on fish anatomy. We also thank Ludovic Hoarau (IFREMER) for his help on ArcGIS. Finally, the authors thank two anonymous reviewers and the associate editor for their very helpful recommendations to improve this manuscript.

Compliance with ethical standards

Funding This work was developed under the project GERMON "N759/DMSOI/2013" funded by European Fisheries Funds EU FEP 2013-2015 and IFREMER.

\section{References}

Alvarado Bremer JR. 1994. Assessment of morphological and genetic variation of the swordfish (Xiphiasgladius Linnaeus): evolutionary patterns of nucleotide substitution in the mitochondrial genome (Doctoral dissertation, $\mathrm{PhD}$ Thesis, University of Toronto, Canada

Ashida H, Tanabe T, Satoh K, Fukui A, Tanaka S, Suzuki N (2010) Reproductive biology of male skipjack tuna katsuwonus pelamis (Linnaeus) in the tropical western and central Pacific Ocean. Fisheries Sci 76:785-793

Barkley R, Neill WH, Gooding RMG (1978) Skipjack tuna, katsuwonus pelamis, habitat based on temperature and oxygen requirements. Fish Bull 76:653-662

Bartlett SE, Davidson WS (1992) FINS (forensically informative nucleotide sequencing): a procedure for identifying the animal origin of biological specimens. Biotechniques 12(3):408-411 
Batalyants K (1989) On the spawning of the skipjack tuna (katsuwonus pelamis). Int. Comm. Conser. Atl. Tunas, col. Vol. Sci. Pap 30(1):20-27

Batts BS (1972) Sexual maturity, fecundity and sex ratios of the skipjack tuna katsuwonus pelamis (Linnaeus), in North Carolina waters. T Am Fish Soc 101:626-637

Brill RW (1994) A review of temperature and oxygen tolerance studies of tunas pertinent to fisheries oceanography, movement models and stock assessments. Fish Oceanogr 3:204-216

Brill RW, Lutcavage ME (2001) Understanding environmental influences on movements and depth distributions of tunas and billfishes can significantly improve population assessment. Am Fish S S 25:179-198

Buñag DM (1956) Spawning habits of some Philippine tuna based on diameter measurements of the ovarian ova. Philipp J Fish 4:145-177

Cayre P, Farrugio H (1986) Biologie de la reproduction du listao (Katsuwonus pelamis) delocean Atlantique. In: Symmons, P.E.K., Miyake, P.M., Sahagawa, G.T. (Eds.), Proc. ICCAT Conf. Int. Skipjack Year Program, Int. Comm. Conser. Atl. Tunas, Madrid, Spain, pp. 252-272

Collette BB, Nauen CE (1983) FAO species catalogue, vol 2. Scombrids of the world. An annotated and illustrated catalogue of tunas, mackerels, bonitos and related species known to date (FAO Fisheries Synopsis no. 125). FAO, Rome

Dueri S, Maury O (2013) Modelling the effect of marine protected areas on the population of skipjack tuna in the Indian Ocean. Aquat Living Resour 26:171-178

Felsenstein J (1985) Confidence limits on phylogenies: an approach using the bootstrap. Evolution 39:783-791

Fonteneau A, Hallier JP (2015) Fifty years of dart tag recoveries for tropical tuna: a global comparison of results for the western Pacific, eastern Pacific, Atlantic and Indian oceans. Fish Res 163:7-22

Fonteneau A (2014) On the recent steady decline of skipjack caught by 
purse seiners in free scholls sets in the eastern Atlantic and western Indian oceans. IOTC-2014-WPTT16-INF02

Grande M, Murua H, Zudaire I, Korta M (2012) Oocyte development and fecundity type of the skipjack Katsuwonus pelamis , in the Western Indian Ocean. J Sea Res 73:117-125

Hall TA (1999) BioEdit: a user-friendly biological sequence alignment editor and analysis program for windows 95/98/NT. Nucleic Acids Symp Ser 41:95-98

IOTC (2014) Indian Ocean Skipjack Tuna Stock Assessment 1950-2013 (Stock Synthesis). IOTC-2014-WPTT16-43 Rev_3

Jones S (1959) Notes on eggs, larvae and juveniles of fishes from Indian waters. III. Katsuwonus pelamis (Linnaeus) and IV.

Neothunnusmacropterus (temminck and Schlegel). Indian Journal of Fisheries 6(2):360-373

Kumar G, Kocour M, Kunal PS (2014) Mitochondrial DNA variation and phylogenetic relationships among five tuna species based on sequencing of D-loop region. Mitochondrial DNA 20:1-5

Kenneth DW (1963) Synopsis of biological data on skipjack (Katsuwonus pelamis) (Linnaeus) 1758 (Pacific Ocean). Species Synopsis N022. FAO Fisheries Biology Synopsis $N^{\circ} 65$

Lelièvre S, Verrez-Bagnis V, Jérôme M, Vaz S (2010) PCR-RFLP analyses of formalin-fixed fish eggs for the mapping of spawning areas in the eastern channel and southern north sea. J Plankton R 32(11):1527-1539

Matsumoto WM, Skillman RA, Dizon AE (1984) Synopsis of biological data on skipjack tuna. Katsuwonus Pelamis NOAA Tech Rep NMFS Circ 451:1-92

Marsac F, Le Blanc JL (1999) Oceanographic changes during the 1997-1998 El Niño in the Indian Ocean and their impact on the purse seine fishery. WPTT99-03, IOTC Proceedings 2:147-157

Ménard F, Marsac F, Bellier E, Cazelles B (2007) Climatic oscillations 
and tuna catch rates in the Indian Ocean: a wavelet approach to time series analysis. Fish Oceanogr 16:95-104

Michelini E, Cevenini L, Mezzanotte L, Simoni P, Baraldini M, De Laude L, Roda A (2007) One-step triplex-polymerase chain reaction assay for the authentication of yellowfin (thunnus albacares), bigeye (thunnus obesus), and skipjack (katsuwonus pelamis) tuna DNA from fresh, frozen, and canned tuna samples. J Agr Food Chem 55:7638-7647

Nei M, Kumar S (2000) Molecular evolution and phylogenetics. Oxford University Press, New York

Nishikawa Y, Honma M, Ueyanagi S, Kikawa S (1985) Average distribution of larvae of oceanic species of scombroid fishes, 1956-1981. Far Seas Fisheries Research Laboratory 12:1-99

Raju G (1964) Studies of the spawning of the oceanic skipjack katsuwonus pelamis (Linnaeus) in Minicoy waters. Symposium Series of the Marine Biological Association of India 1(2):744-768

Saitou N, Nei M (1987) The neighbor-joining method: a new method for reconstructing phylogenetic trees. Mol Biol Evol 4:406-425

Schaefer MB, Orange CJ (1956) Studies of the sexual development and spawning of yellowfin tuna (neothunnusmacropterus) and skipjack (katsuwonus pelamis) in three areas of the eastern Pacific Ocean, by examination of gonads. Inter-American Tropical Tuna Commission Bulletin 1:283-349

Schaefer KM (2001) Assessment of skipjack tuna (katsuwonus pelamis) spawning activity in the eastern Pacific Ocean. Fish Bull 99:343-350

Smith MM, Heemstra PC (1986) Smith's sea fishes. Springer-Verlag, Berlin Heidelberg New York Paris Tokyo In Chapter Scombridae page 834

Stéquert B (1976) Stade de la maturité sexuelle, de la Ponte et de la fécondité du listao (katsuwonus pelamis) de la Côte Nord-Ouest de Madagascar. Cahiers ORSTOM. Série Océanographie 14:227-247

Stéquert B, Ramcharrun B (1995) La fécondité du listao (katsuwonus 
pelamis) de l'Ouest de l'océan Indien. Aquat. Living. Ressour. 8:79-89

Stéquert B, Ramcharrun B (1996) La reproduction du listao (katsuwonus pelamis) dans le bassin Ouest de l'océan Indien. Aquat. Living. Ressour. 9:235-247

Stéquert B, Nuñez Rodríguez J, Cuisset B, Le Menn F (2001) Gonadosomatic index and seasonal variations of plasma sex steroids in skipjack tuna (katsuwonus pelamis) and yellowfin tuna (thunnus albacares) from the western Indian Ocean. Aquat Living Ressour 14:313-318

Tamura K, Stecher G, Peterson D, Filipski A, Kumar S (2013) MEGA6: molecular evolutionary genetics analysis version 6.0. Mol Biol Evol $30: 2725-2729$

Viñas J, Tudela S (2009) A validated methodology for genetic identification of tuna species (genus thunnus). PLoS One 4(10):e7606 